\title{
Ceria-carbonate Electrolyte Ceramic Membrane for Intermediate and Low Temperature Solid Oxide Fuel Cells: A Review
}

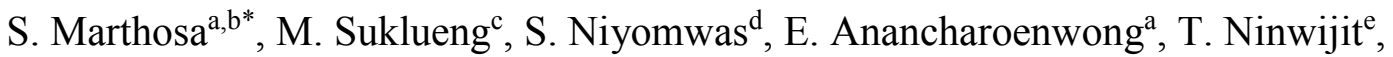 \\ N. Budmai ${ }^{\text {a }}$ S S. Kaewnun ${ }^{\text {a }}$ \\ ${ }^{a}$ Faculty of Science and Industrial Technology, Prince of Songkla University, \\ Suratthani Campus, Surat Thani 84000, Thailand \\ ${ }^{\mathrm{b}}$ Center of Excellence in Membrane Science and Technology (CoEMST), \\ Prince of Songkla University, Hat Yai, Songkhla 90110, Thailand \\ 'PSU Energy Systems Research Institute (PERIN), Interdisciplinary Graduate School \\ of Energy Systems, Prince of Songkla University, Hat Yai, Songkhla 90110, Thailand \\ ${ }^{\mathrm{d}}$ Department of Mechanical Engineering, Faculty of Engineering, \\ Prince of Songkla University, Hat Yai, Songkhla 90110, Thailand \\ eEnergy Technology Program, Faculty of Engineering, \\ Prince of Songkla University, Hat Yai, Songkhla 90110, Thailand
}

Submitted: 14/7/2019. Revised edition: 17/2/2019. Accepted: 17/10/2019. Available online: 5/3/2020

\begin{abstract}
A solid oxide fuel cell (SOFC) is a potential energy conversion technology with high efficiency and high fuel impurity tolerance. Its electrolyte layer is a crucial component and a novel ceria-carbonate electrolyte ceramic membrane has been developed for the intermediate and low temperature SOFCs (IT-LT SOFCs). The ceria-carbonate electrolyte can be produced by either a two-steps process which produces microscale particles or a one-step process which produces nanoscale materials. The ceria-carbonate composite ceramic membrane facilitates both of the oxide ion and proton conductions thus this material has a potential to raise the multi-ions transportation and improve performance of IT-LT SOFCs.
\end{abstract}

Keywords: Ceramic membrane, SOFC, carbonate, conductivity

\subsection{INTRODUCTION}

Fuel cell is an alternative energy conversion technology which converts chemical energy to electrical energy through an electrochemical reaction. A fuel cell unit is consisted of anode, electrolyte and cathode. The electrolyte layer prohibits gas and electron transportations but conducts ions. There are many types of fuel cells available and this review focuses on development of an electrolyte ceramic membrane in solid oxide fuel cells (SOFCs).
SOFC is a ceramic based fuel cell which operates at high temperature in the range of $800-1,000{ }^{\circ} \mathrm{C}$ [1]. It can tolerate high impurities in fuel thus it can operate using the abundant natural gas and biogas [2]. SOFCs technology is commonly used in a stationery power plant. The ion conducting electrolyte ceramic membrane in SOFCs is crucial to the fuel cell performance. It must eliminate the crossover between fuel and oxidant from the electrodes, allow the ion conduction and minimize the electrical 
conduction. The operating principles of SOFCs is shown in Figure 1.

Oxygen $\left(\mathrm{O}_{2}\right)$ is used as the oxidant for SOFCs, oxygen enters and diffuses through cathode to react with the conducted electrons $\left(\mathrm{e}^{-}\right)$, producing oxygen ion $\left(\mathrm{O}^{2-}\right)$ which is then transported to electrolyte layer (see Equation 1).

Cathode: $\mathrm{O}_{2}+4 \mathrm{e}^{-} \leftrightarrow 2 \mathrm{O}^{2-}$

At anode, hydrogen $\left(\mathrm{H}_{2}\right)$ fuel enters and diffuses through anode, then reacts to produce proton $\left(\mathrm{H}^{+}\right)$and electron $\left(\mathrm{e}^{-}\right.$ ). Proton reacts with the oxygen ions, forming water while electron moves through the external circuit (see Equation 2) to cathode. The overall reaction is shown in Equation 3.

Anode: $\mathrm{H}_{2}+2 \mathrm{O}^{2-} \leftrightarrow \mathrm{H}_{2} \mathrm{O}+4 \mathrm{e}^{-}$

Overall: $\mathrm{H}_{2}+\mathrm{O}_{2} \leftrightarrow \mathrm{H}_{2} \mathrm{O}$

According to chemical reactions described above, the electrolyte is an oxygen ion conducting materials illustrated in works from Phaijit, Suklueng [2] and Hong, Lee [3].

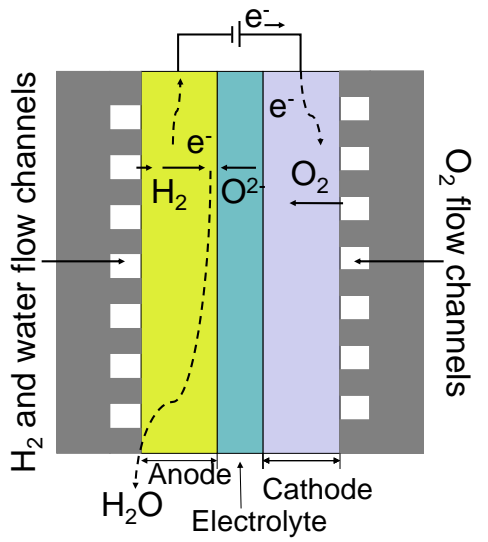

Figure 1 Operating principle of a solid oxide fuel cell

However, the recent developments in SOFCs research have utilized many of the novel electrolyte membranes with multi-ions transportation property. These novel membranes are known as caria-carbonate electrolyte membranes.
This article investigates the available preparation methods, the multi-ions mechanism and the related SOFCs performance.

\subsection{Electrolyte Membranes}

Solid oxide fuel cells typically operate approximately $800-1,000{ }^{\circ} \mathrm{C}$. The high operating temperature leads to a high material corrosion, requirement of a high temperature sealant, low mechanical stability and challenges for engineering of many components [3-5]. As a consequent, significant number of researches have focused on developing the intermediate and low temperature SOCFs (IT-LT SOFCs). Researchers have been able to reduce the operating temperature of SOFCs to be less than $600{ }^{\circ} \mathrm{C}$ thus a new composite electrolyte for IT-LT SOFCs is sorted after [6].

Lowering the SOFCs operating temperature increases the ionic resistance to the ion transportation in the electrolyte (high ohmic loss), thus IT-LT SOFCs require an electrolyte with higher ionic conductivity and a cathode with higher reaction activity, in comparison to the high temperature SOFCs [7]. The operating temperature of the intermediate temperature SOFCs (IT-SOFCs) and the low temperature SOFCs (LT-SOFCs) are typically referred to as $600-800{ }^{\circ} \mathrm{C}$ [4] and 300 $600{ }^{\circ} \mathrm{C}[3,8]$, respectively.

Yttria stabilized zirconia (YSZ) is commonly chosen for the high temperature SOFCs because it has high ionic conductivity at $800{ }^{\circ} \mathrm{C}$ [9]. However, it can poorly conduct ions at temperature less than $600{ }^{\circ} \mathrm{C}$. Pure cerium (Ce) electrolyte material have been studied and it was found that a pure ceria-based electrolyte cannot conduct ion well. Researchers commonly doped the ceria-based electrolyte with low valence cation such as gadolinium cation $\left(\mathrm{Gd}^{3+}\right)$, to 
produce gadolinium dope ceria (GDC) electrolyte, and samarium cation $\left(\mathrm{Sm}^{3+}\right)$ to deliver samarium doped ceria (SDC) electrolyte $[10,11]$.

Many researchers suggested that increasing the samarium content could cause a significant increase in oxygen vacancy which increased the ionic conductivity. GDC and SDC have an ionic conductivity level of $0.1 \mathrm{~S} \mathrm{~cm}^{-1}$ at temperature below $600{ }^{\circ} \mathrm{C}[12]$. The doped cation increases oxygen vacancy in electrolyte at temperature less than $600{ }^{\circ} \mathrm{C}$ thus GDC and SDC are more conductive than the pure ceria electrolyte.

\subsection{Ceria-carbonate Electrolyte Membrane}

Ceria-based electrolyte such as GDC and SDC are suitable for IT-SOFC applications due to its excellent ionic conductivity, good stability and compatibility with other fuel cell components. However, they showed a mixed ionic-electronic conducting behavior, which effectively decreased the overall fuel cell efficiency at temperature lower than $400{ }^{\circ} \mathrm{C}$ [4].

To improve its ionic conductivity, many researches added a second phase of carbonate salts to suppress the electronic conduction. Note that the electronic conduction is a result of reduction of $\mathrm{Ce}^{4+}[13]$. Ceria ion $\left(\mathrm{Ce}^{4+}\right)$ in the ceria-based electrolyte reduces to $\mathrm{Ce}^{3+}$ in the fuel cell operating environment and leads to the electronic conduction in the electrolyte. The second phase of the carbonate salts can suppress the induced electronic conduction $[14,15]$ in electrolyte. The preparation processes and operating principles of ionic conduction in the ceria-carbonate electrolyte are presented in the following sections.

\subsection{CERIA-CARBONATE MEMBRANE PREPARATION}

The ionic conductivity of the electrolyte can be influenced by many factors such as the composite materials, grain boundary, grain size, processing conditions, sintering temperature $[16,17], \quad$ sintering methods [18] and the preparation methods [19]. This review investigates the preparation of the ceria-carbonate composite electrolyte undertaken recently and they were grouped into the two-steps process and the one-step process.

\subsection{Two-steps Process}

The ceria-carbonate electrolyte such as SDC-carbonate electrolyte can be prepared in two-steps process. In the first step, SDC is prepared by various methods which can be solid state reaction, sol-gel, glycine-nitrate combustion, oxalate co-precipitation or carbonate co-precipitation. In the second step, SDC is thoroughly mixed with carbonate by either the mechanical milling in the solid state method [20] or the wet mixing method [21].

\subsubsection{Solid State Reaction}

This method mixes samarium oxide $\left(\mathrm{Sm}_{2} \mathrm{O}_{3}\right)$ and cerium oxide $\left(\mathrm{Ce}_{2} \mathrm{O}_{3}\right)$ in mechanical milling, repetition of drying, mixing to ensure homogenous mixing of the composites and sintering the composite at high temperature (more than $1,000{ }^{\circ} \mathrm{C}$ ). Small grain size can increase the electronic conductivity, decreases the activation energy for ceria structure electrolyte [10] thus the preparation method is crucial toward the electrolyte performance. 


\subsubsection{Glycine-nitrate Process}

Huang, Mao [22] prepared SDC from glycine-nitrate process (GNP) technique. Cerium nitrate $\left(\mathrm{Ce}\left(\mathrm{NO}_{3}\right)_{3} \cdot 6 \mathrm{H}_{2} \mathrm{O}\right)$ and samarium oxide $\left(\mathrm{Sm}_{2} \mathrm{O}_{3}\right)$ were dissolved in a dilute nitrate acid to produce a precursor solution which was then blended with glycine. The blended solution was then heated till combust and the SDC "ash" was collected, calcined at $750^{\circ} \mathrm{C}$ for 2 $\mathrm{h}$ to produce SDC electrolyte powder.

\subsubsection{Sol-gel Method}

Xia, Li [19] prepared SDC electrolyte by sol-gel method as according to procedure described by Huang, Shuk [23]. Cerium nitrate $\left(\mathrm{Ce}\left(\mathrm{NO}_{3}\right)_{3} \cdot 6 \mathrm{H}_{2} \mathrm{O}\right)$ and samarium nitrate $\left(\mathrm{Sm}\left(\mathrm{NO}_{3}\right)_{3} \cdot 6 \mathrm{H}_{2} \mathrm{O}\right)$ were separately dissolved in water before the solutions were mixed and then co-precipitated with ammonium hydroxide at $\mathrm{pH}$ of 10. The precipitation was carried out at a stable $\mathrm{pH}$ of 3.3. The sol was placed in a $95{ }^{\circ} \mathrm{C}$ drying oven, where transformation of sol-to-gel occurred over a period of 1-2 days. The gel was heated at $1000{ }^{\circ} \mathrm{C}$ for $2-3 \mathrm{~h}$ to produce SDC powder.

\subsubsection{Oxalate Method}

Huang, Mao [22] and Huang, Gao [6] prepared SDC electrolyte by oxalate co-precipitation. $\mathrm{Ce}\left(\mathrm{NO}_{3}\right)_{3} \cdot 6 \mathrm{H}_{2} \mathrm{O}$ and $\mathrm{Sm}_{2} \mathrm{O}_{3}$ were dissolved in dilute nitrate acid to produce a precursor solution which was then dripped into oxalate acid solution with a neutral $\mathrm{pH}$ between 6.6 and 6.9. The obtained precipitate was collected, washed by water and ethanol and calcined at 750 ${ }^{\circ} \mathrm{C}$ for $2 \mathrm{~h}$ to form SDC powder.

\subsubsection{Carbonate Co-precipitation Method}

Wang, Ma [21] prepared SDC electrolyte by dissolved cerium nitrate $\left(\mathrm{Ce}\left(\mathrm{NO}_{3}\right)_{3} \cdot 6 \mathrm{H}_{2} \mathrm{O}\right)$ and samarium nitrate $\left(\mathrm{Sm}\left(\mathrm{NO}_{3}\right)_{3} \cdot 6 \mathrm{H}_{2} \mathrm{O}\right)$ in water with molar ration of $\mathrm{Ce}^{3+}: \mathrm{Sm}^{3+}=4: 1$ to form a 0.5 molL ${ }^{-1}$ solution. The solution was dropwise added into $0.5 \mathrm{molL}^{-1}$ sodium carbonate $\left(\mathrm{Na}_{2} \mathrm{CO}_{3}\right)$ solution under vigorous stirring to form a white precipitate at room temperature. The precipitate was filtered, washed by distilled water, dried at $80^{\circ} \mathrm{C}$.

The obtained SDC powder were mixed with carbonate salts as mentioned earlier to produce SDCcarbonate powder. The composite powder was then hydraulic pressed at $300 \mathrm{MPa}$ and sintered to form an electrolyte pellet. Sintering of the ceria-carbonate electrolyte have been carried out at various temperatures depending on the SDC preparation methods. Zhu [24] found that the repetition of sintering of the composite membrane electrolyte form larger particles which reduced the interfacial area between SDC crystal phase and the carbonate phase, leading to the lower conductivity.

Properties of the SDC-carbonate ceramic membrane from the two-steps processes varied with manufacturing batches [13]. The loss of carbonate salt during the second step was encountered thus it was difficult to control carbonate content and the composite size [13]. Due to these reasons, a single step preparation of SDC-carbonate has been studied to eliminate these limitations. 


\subsection{One-step Process}

In 2010, Raza, Wang [25] first reported on a one-step process for SDC-carbonate composite electrolyte preparation. Then in 2013, Jing, Patakangas [13] reported a different one-step process.

\subsubsection{Chemical Co-precipitation}

Raza, Wang [25] and Gao, Raza [26] developed a one-step process to produce a SDC-carbonate composite electrolyte using a chemical coprecipitation process. $1.0 \mathrm{M}$ solution of cerium nitrate $\left(\mathrm{Ce}\left(\mathrm{NO}_{3}\right)_{3} \cdot 6 \mathrm{H}_{2} \mathrm{O}\right)$ and samarium nitrate $\left(\mathrm{Sm}\left(\mathrm{NO}_{3}\right)_{3} \cdot 6 \mathrm{H}_{2} \mathrm{O}\right)$ were mixed, then an amount of $1.0 \mathrm{M}$ sodium carbonate $\left(\mathrm{Na}_{2} \mathrm{CO}_{3}\right)$ was added slowly $\left(10 \mathrm{ml} \mathrm{min}^{-1}\right)$ to the nitrate mixture. After that, the ceria-carbonate solution was filtered by a suction filtration method. The precipitate was dried overnight at $50{ }^{\circ} \mathrm{C}$ before being grinded thoroughly and sintered at 800 ${ }^{\circ} \mathrm{C}$ for $2 \mathrm{~h}$. The scanning electron microscope (SEM) images shows that the SDC-carbonate prepared by the novel method was tetrahedron shape in nanoscale 30-100 nm. The transmission electron microscope (TEM) images shows that the carbonate coated SDC surface and the carbonate was in an amorphous phase - facilitating the ionic conduction in the electrolyte membrane.

\subsubsection{Freeze-dried Method}

Jing, Patakangas [13] have reported a successful SDC-carbonate preparation in an improved freeze-dried method based on the formation of lanthanide citrate complex solution-gel. Cerium nitrate $\left(\mathrm{Ce}\left(\mathrm{NO}_{3}\right)_{3} \cdot 6 \mathrm{H}_{2} \mathrm{O}\right)$ and samarium nitrate $\left(\mathrm{Sm}\left(\mathrm{NO}_{3}\right)_{3} .6 \mathrm{H}_{2} \mathrm{O}\right)$ were dissolved in water. The nitrate solution was stirred while adding citric acid and it was precipitated via addition of ammonia solution. $\mathrm{pH}$ was kept above 10. The carbonate salt solution was prepared by using $\mathrm{Na}_{2} \mathrm{CO}_{3}, \mathrm{Li}_{2} \mathrm{CO}_{3}$ and $\mathrm{K}_{2} \mathrm{CO}_{3}$ powders. Then the carbonate salt solution and the ethylene glycol were poured into the nitrate solution. The mixture was freeze-dried by liquid nitrogen, water was removed from the frozen solution. The mixed crystal was sintered at $800{ }^{\circ} \mathrm{C}$ after drying and the SDC-carbonate powder was obtained as a white porous powder. The Energy Dispersive X-Ray (EDS) element distribution revealed that $\mathrm{Li}_{2} \mathrm{CO}_{3}$, $\mathrm{Na}_{2} \mathrm{CO}_{3}$ and $\mathrm{K}_{2} \mathrm{CO}_{3}$ appeared in the prepared electrolyte. The x-ray diffraction (XRD) spectra for the carbonate within $30-48^{\circ}$ were low thus most of the carbonate was in the amorphous state. The ionic conductivity increased rapidly between $350-400{ }^{\circ} \mathrm{C}$. At temperature higher than $400{ }^{\circ} \mathrm{C}$, it was almost linear, this might be due to the softening of the carbonate phase. The highest ionic conductivity was $0.4 \mathrm{Scm}^{-1}$ at $600{ }^{\circ} \mathrm{C}$.

\subsection{MULTI-IONS \\ TRANSPORTATION IN SDC- CARBONATE ELECTROLYTE AND PERFORMANCE}

The integration of SDC and carbonate via the 2-steps and the 1-step methods creates composite electrolyte materials with multi-ions transportation mechanism. Referring to Figure 1, the electrolyte allows only the oxygen ion trough but in a multi-ions system, the proton, carbonate ions and the oxygen ions are allowed through it. In order to investigate the multi-ions system Gao, Raza [26] used the I-V polarization curve to determine conductivity of specific ions in the multi-ions system of $\mathrm{H}^{+}$and $\mathrm{O}^{2-}$ fuel cells. It was found that the carbonate phase contributed for the proton $\left(\mathrm{H}^{+}\right)$conduction while 
the SDC phase contributed for the oxygen ions $\left(\mathrm{O}^{2-}\right)$ conduction.

The ionic conductivity of the composite electrolyte membrane increased with the increasing carbonate content [27]. Despite the benefit of carbonate phase, a suitable doping concentration was needed. Huang, Gao [6] prepared the doped ceria-carbonate electrolyte via oxalate co-precipitation: SDC-20wt $\%(0.53 \mathrm{Li} / 0.47 \mathrm{Na})_{2} \mathrm{CO}_{3}$ and SDC-30wt $\%(0.67 \mathrm{Li} / 0.33 \mathrm{Na})_{2} \mathrm{CO}_{3}$ and found that the $30 \mathrm{wt} \%$ carbonate addition produced a fuel cell with higher power output than the $20 \mathrm{wt} \%$ sample. However, an excessive amount of carbonate phase caused a severe phase separation between SDC and carbonate in the electrolyte, hence an unstable fuel cell performance.

Gao, Raza [26] prepared the SDC$\mathrm{Na}_{2} \mathrm{CO}_{3}$ via the 2-steps method (solid state reaction) and the 1-step method (chemical co-precipitation). The electrolyte morphology of the solidstate method shows microscale structure whereas those prepared by the 1-step method shows nanoscale structure. The $\mathrm{SDC}-\mathrm{Na}_{2} \mathrm{CO}_{3}$ nanocomposite had conductivity about one to several times higher than the $\mathrm{SDC}-\mathrm{Na}_{2} \mathrm{CO}_{3}$ microcomposite. The nanocomposite provides high interfacial region between SDC and carbonate phase; increases the ionic conductivity pathway and increases the interfacial mobile ion concentration in the bulk [26]. A theoretical description by Yin, Ye [28] also agreed with the experimental result on the benefit of the interfacial surface between SDC and carbonate toward the improved conductivity.

Table 1 Performance of fuel cells with SDC-carbonate electrolytes

\begin{tabular}{|c|c|c|c|c|c|}
\hline \multirow[b]{2}{*}{ Ref } & \multirow[b]{2}{*}{$\begin{array}{c}\text { Operating } \\
\text { Temp } \\
{\left[{ }^{\circ} \mathrm{C}\right]}\end{array}$} & \multirow{2}{*}{$\begin{array}{c}\text { Electrolyte } \\
\text { preparation } \\
\text { method }\end{array}$} & \multicolumn{2}{|c|}{ Performance } & \multirow[b]{2}{*}{ Electrolyte } \\
\hline & & & 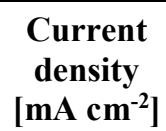 & $\begin{array}{c}\text { Peak } \\
\text { Power } \\
{\left[\mathbf{m W} \mathbf{c m}^{-2}\right]}\end{array}$ & \\
\hline$[22]$ & 400 & $\begin{array}{l}{ }^{\mathrm{II} O x a l a t e} \text { co- } \\
\text { precipitation }\end{array}$ & 680 & 330 & SDC-30wt $\%\left(2 \mathrm{Li}_{2} \mathrm{CO}_{3}: 1 \mathrm{Na}_{2} \mathrm{CO}_{3}\right)$ \\
\hline$[26]$ & 400 & $\begin{array}{l}{ }^{\mathrm{I}} \text { Chemical co- } \\
\text { precipitation }\end{array}$ & 400 & 130 & $\mathrm{SDC}-33 \mathrm{wt} \% \mathrm{Na}_{2} \mathrm{CO}_{3}$ \\
\hline$[22]$ & 450 & $\begin{array}{l}{ }^{\mathrm{II}} \text { Oxalate co- } \\
\text { precipitation }\end{array}$ & 850 & 420 & $\mathrm{SDC}-30 \mathrm{wt} \%\left(2 \mathrm{Li}_{2} \mathrm{CO}_{3}: 1 \mathrm{Na}_{2} \mathrm{CO}_{3}\right)$ \\
\hline$[22]$ & 450 & $\begin{array}{l}\text { II Glycine-nitrate } \\
\text { process }\end{array}$ & 680 & 250 & $\mathrm{SDC}-30 \mathrm{wt} \%\left(2 \mathrm{Li}_{2} \mathrm{CO}_{3}: 1 \mathrm{Na}_{2} \mathrm{CO}_{3}\right)$ \\
\hline$[26]$ & 450 & $\begin{array}{l}{ }^{\mathrm{I}} \text { Chemical co- } \\
\text { precipitation }\end{array}$ & 850 & 310 & $\mathrm{SDC}-33 \mathrm{wt} \% \mathrm{Na}_{2} \mathrm{CO}_{3}$ \\
\hline$[6]$ & 500 & $\begin{array}{l}{ }^{\mathrm{II}} \text { Oxalate co- } \\
\text { precipitation }\end{array}$ & 700 & 350 & $\mathrm{SDC}-20 \mathrm{wt} \%(0.53 \mathrm{Li} / 0.47 \mathrm{Na})_{2} \mathrm{CO}_{3}$ \\
\hline$[6]$ & 500 & $\begin{array}{l}\text { IIOxalate co- } \\
\text { precipitation }\end{array}$ & 800 & 380 & $\mathrm{SDC}-30 \mathrm{wt} \%(0.67 \mathrm{Li} / 0.33 \mathrm{Na})_{2} \mathrm{CO}_{3}$ \\
\hline$[22]$ & 500 & $\begin{array}{l}\text { II Oxalate co- } \\
\text { precipitation }\end{array}$ & 1350 & 620 & $\mathrm{SDC}-30 \mathrm{wt} \%\left(2 \mathrm{Li}_{2} \mathrm{CO}_{3}: 1 \mathrm{Na}_{2} \mathrm{CO}_{3}\right)$ \\
\hline$[22]$ & 500 & $\begin{array}{l}\text { II Glycine-nitrate } \\
\text { process }\end{array}$ & 1500 & 540 & $\mathrm{SDC}-30 \mathrm{wt} \%\left(2 \mathrm{Li}_{2} \mathrm{CO}_{3}: 1 \mathrm{Na}_{2} \mathrm{CO}_{3}\right)$ \\
\hline$[26]$ & 500 & $\begin{array}{l}{ }^{\mathrm{I}} \text { Chemical co- } \\
\text { precipitation }\end{array}$ & 900 & 460 & $\mathrm{SDC}-33 \mathrm{wt} \% \mathrm{Na}_{2} \mathrm{CO}_{3}$ \\
\hline$[6]$ & 550 & $\begin{array}{l}\text { IIOxalate co- } \\
\text { precipitation }\end{array}$ & 800 & 380 & $\mathrm{SDC}-20 \mathrm{wt} \%(0.53 \mathrm{Li} / 0.47 \mathrm{Na}){ }_{2} \mathrm{CO}_{3}$ \\
\hline$[6]$ & 550 & $\begin{array}{l}{ }^{\mathrm{II}} \text { Oxalate co- } \\
\text { precipitation }\end{array}$ & 1150 & 575 & $\mathrm{SDC}-30 \mathrm{wt} \%(0.67 \mathrm{Li} / 0.33 \mathrm{Na})_{2} \mathrm{CO}_{3}$ \\
\hline
\end{tabular}




\begin{tabular}{|c|c|c|c|c|c|}
\hline \multirow[b]{2}{*}{ Ref } & \multirow{2}{*}{$\begin{array}{c}\text { Operating } \\
\text { Temp } \\
{\left[{ }^{\circ} \mathrm{C}\right]}\end{array}$} & \multirow{2}{*}{$\begin{array}{c}\text { Electrolyte } \\
\text { preparation } \\
\text { method }\end{array}$} & \multicolumn{2}{|c|}{ Performance } & \multirow[b]{2}{*}{ Electrolyte } \\
\hline & & & $\begin{array}{c}\text { Current } \\
\text { density } \\
{\left[\mathrm{mA} \mathbf{c m}^{-2}\right]}\end{array}$ & $\begin{array}{c}\text { Peak } \\
\text { Power } \\
{\left[\mathrm{mW} \mathbf{c m}^{-2}\right]}\end{array}$ & \\
\hline [22] & 550 & $\begin{array}{l}{ }^{\mathrm{II}} \text { Oxalate co- } \\
\text { precipitation }\end{array}$ & 2100 & 900 & SDC-30wt $\%\left(2 \mathrm{Li}_{2} \mathrm{CO}_{3}: 1 \mathrm{Na}_{2} \mathrm{CO}_{3}\right)$ \\
\hline [22] & 550 & $\begin{array}{l}\text { II Glycine-nitrate } \\
\text { process }\end{array}$ & 1450 & 750 & SDC-30wt $\%\left(2 \mathrm{Li}_{2} \mathrm{CO}_{3}: 1 \mathrm{Na}_{2} \mathrm{CO}_{3}\right)$ \\
\hline [26] & 550 & $\begin{array}{l}{ }^{\mathrm{I}} \text { Chemical co- } \\
\text { precipitation }\end{array}$ & 1050 & 510 & $\mathrm{SDC}-33 \mathrm{wt} \% \mathrm{Na}_{2} \mathrm{CO}_{3}$ \\
\hline
\end{tabular}

Where II indicates 2-steps method and I indicate 1-step method

Table 1 shows performance of fuel cells with SDC-carbonate electrolytes which were prepared by the 2-steps and 1-step methods at operating temperatures in the rage of $400-550{ }^{\circ} \mathrm{C}$. Although the comparison cannot be made directly due to different carbonate were used. The peak power density of fuel cell with chemical co-precipitation (1-step method) is in the similar range of values corresponding to the 2-steps methods.

The schematic working principle of the oxygen ion conducting electrolyte is already presented in Figure 1. A schematic diagram for the proton conducting electrolyte is explained in Figure 2 where water is produced at cathode.

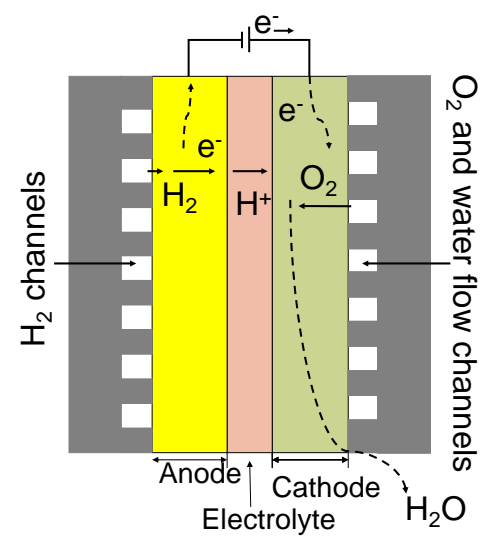

Figure 2 Operating principle of a SOFC with proton conducting electrolyte

For the $\mathrm{H}^{+}$conduction electrolyte membrane, hydrogen molecules dissociate to proton and electron at anode. Proton is transported through electrolyte then interreacts with oxygen molecules and electron at cathode. Water is therefore produced at cathode (see Equation 4-6).

Anode: $\mathrm{H}_{2} \leftrightarrow \mathrm{H}^{+}+\mathrm{e}^{-}$

Cathode: $\mathrm{O}_{2}+\mathrm{H}^{+}+\mathrm{e}^{-} \leftrightarrow \mathrm{H}_{2} \mathrm{O}$

Overall: $\mathrm{H}_{2}+\mathrm{O}_{2} \leftrightarrow \mathrm{H}_{2} \mathrm{O}$

$\mathrm{Li}$ and Sun [29] designed an experiment to collect water during operation of fuel cells with SDCcarbonate electrolyte. Water was collected from both electrodes thus it was evident that the ceria-carbonate electrolyte was the multi-ions conducting materials and effectively enhanced the fuel cell performance.

The multi-ionic conducting behavior of ceria-carbonate electrolyte ceramic membrane has offered a novel material for many advanced applications such as ammonia synthesis, bio fuel cells and carbon dioxide separation. Evidently, the ceria-carbonate electrolyte has lowered the operating temperature for SOFCs and its reversed mode of fuel cell, i.e. electrolysis [30] were also possible to use the novel ceria-carbonate electrolyte. Exciting fuel source such as methanol vapour can be applied to the novel low temperature SOFCs [31]. Furthermore, the proton conduction electrolyte finds its use in the low pressure electrochemical ammonia synthesis process [32]. The carbonate ion 
conduction has placed the electrolyte to be a candidate membrane for high temperature $\mathrm{CO}_{2}$ separation [33].

\subsection{CONCLUSION}

A ceria-carbonate electrolyte is a promising electrolyte for the intermediate and low temperature solid oxide fuel cells. The second phase of carbonate improves the ionic conductivity at low temperature range. Preparation method of the 2-steps and 1-step were investigated. There are evidences confirming that the ceriacarbonate electrolytes exhibit the multiionic conducting behavior. According to the multi-ionic conduction, the ceriacarbonate electrolyte membrane is a candidate membrane for an intermediate and low temperature solid oxide fuel cells.

\section{ACKNOWLEDGEMENT}

The authors would like to thank PERIN and CoEMST at Prince of Songkla University for providing facilities and guides to finish this project.

\section{REFERENCES}

[1] Marthosa, S. 2012. Improvement of Electrocatalyst Performance in Hydrogen Fuel Cells by Multiscale Modelling. Ph.D. Thesis. University of Manchester.

[2] Phaijit, S., M. Suklueng, S. Marthosa, S. Niyomwas, N. Y. Voo, and A. Kumar. 2019. A Novel Micro-solid Oxide Fuel Cell ( $\mu$-SOFC) for Detecting Methane Content in Biogas. Bulletin of Materials Science. 42(3).
[3] Hong, S., D. Lee, H. Yang, and Y. B. Kim. 2018. Direct Hydrothermal Growth of GDC Nanorods for Low Temperature Solid Oxide Fuel Cells. Applied Surface Science. 444: 430-435.

[4] Tanwar, K., N. Jaiswal, V. D. Bhargavi, K. Bhimani, D. Kumar, and O. Parkash. 2016. Effect of Carbonates Addition on Ce0.80Gd0.2001.90 (GDC) Nanorods Prepared by Wet Chemical Route for LT-SOFCs. International Journal of Hydrogen Energy. 41(47): 22354-22360.

[5] Li, T., Z. T. Wu, and K. Li. 2014. Single-step Fabrication and Characterisations of Triplelayer Ceramic Hollow Fibres for Micro-tubular Solid Oxide Fuel Cells (SOFCs). Journal of Membrane Science. 449: 1-8.

[6] Huang, J. B., R. F. Gao, Z. Q. Mao, and J. Y. Feng. 2010. Investigation of $\mathrm{La}_{2} \mathrm{NiO}_{4+\delta}$-based Cathodes for SDC-carbonate Composite Electrolyte Intermediate Temperature Fuel Cells. International Journal of Hydrogen Energy. 35(7): $2657-$ 2662.

[7] Mahato, N., A. Gupta, and K. Balani. 2011. Doped Zirconia And Ceria-based Eletrolytes for Solid Oxide Fuel Cells: A Review. Nanomaterials and Energy. 1(NME1): 27-45.

[8] Khan, I., M. I. Asghar, P. D. Lund, and S. Basu. 2017. High Conductive $(\mathrm{LiNaK})_{2} \mathrm{CO}_{3}-$ $\mathrm{Ce}_{0.85} \mathrm{Sm}_{0.15} \mathrm{O}_{2} \quad$ Electrolyte Compositions for IT-SOFC Applications. International Journal of Hydrogen Energy. 42(32): 20904-20909.

[9] Kim, J. H., S. S. Shin, H. S. Noh, J. W. Son, M. Choi, and H. Kim. 2017. Tailoring Ceramic Membrane Structures of Solid 
Oxide Fuel Cells Via Polymerassisted Electrospray Deposition. Journal of Membrane Science. 544: 234-242.

[10] Hui, S. Q., J. Roller, S. Yick, X. Zhang, C. Deces-Petit, Y. S. Xie, R. Maric, and D. Ghosh. 2007. A Brief Review of the Ionic Conductivity Enhancement for Selected Oxide Electrolytes. Journal of Power Sources. 172(2): 493-502.

[11] Sun, W. P., Z. Shi, Z. T. Wang, and W. Liu. 2015. Bilayered $\mathrm{BaZr}_{0.1} \mathrm{Ce}_{0.7} \mathrm{Y}_{0.2} \mathrm{O}_{3-}$

${ }_{\delta} / \mathrm{Ce}_{0.8} \mathrm{Sm}_{0.2} \mathrm{O}_{2-\delta} \quad$ Electrolyte Membranes for Solid Oxide Fuel Cells with High Open Circuit Voltages. Journal of Membrane Science. 476: 394-398.

[12] Boden, A., J. Di, C. Lagergren, G. Lindbergh, and C. Y. Wang. 2007. Conductivity of SDC and $(\mathrm{Li} / \mathrm{Na})_{2} \mathrm{CO}_{3} \quad$ Composite Electrolytes in Reducing and Oxidising Atmospheres. Journal of Power Sources. 172(2): 520529.

[13] Jing, Y. F., J. Patakangas, P. D. Lund, and B. Zhu. 2013. An Improved Synthesis Method of Ceria-carbonate based Composite Electrolytes for Lowtemperature SOFC Fuel Cells. International Journal of Hydrogen Energy. $38(36)$ : 16532-16538.

[14] Zhu, B., X. G. Liu, M. T. Sun, S. J. Ji, and J. C. Sun. 2003. Calcium Doped Ceria-based Materials for Cost-effective Intermediate Temperature Solid Oxide Fuel Cells. Solid State Sciences. 5(8): 1127-1134.

[15] Huang, H. B., Z. Q. Mao, Z. X. Liu, and C. Wang. 2007. Development of Novel Lowtemperature SOFCs with Coionic Conducting SDC-carbonate Composite Electrolytes.
Electrochemistry

Communications. 9(10): 26012605.

[16] Ali, S. A. M., A. Muchtar, A. B. Sulong, N. Muhamad, and E. H. Majlan. 2013. Influence of Sintering Temperature on the Power Density of Samariumdoped-ceria Carbonate Electrolyte Composites for Lowtemperature Solid Oxide Fuel Cells. Ceramics International. 39(5): 5813-5820.

[17] Ali, S. A. M., R. E. Rosli, A. Muchtar, A. B. Sulong, M. R. Somalu, and E. H. Majlan. 2015. Effect of Sintering Temperature on Surface Morphology and Electrical Properties of Samarium-doped Ceria Carbonate for Solid Oxide Fuel Cells. Ceramics International. 41(1): 1323-1332.

[18] Xu, X., L. Bi, and X. S. Zhao. 2018. Highly-conductive Protonconducting Electrolyte Membranes with a Low Sintering Temperature for Solid Oxide Fuel Cells. Journal of Membrane Science. 558: 17-25.

[19] Xia, C., Y. Li, Y. Tian, Q. H. Liu, Z. M. Wang, L. J. Jia, Y. C. Zhao, and Y. D. Li. 2010. Intermediate Temperature Fuel Cell with a Doped Ceriacarbonate Composite Electrolyte. Journal of Power Sources. 195(10): 3149-3154.

[20] Asghar, M. I., M. Heikkila, and P. D. Lund. 2017. Advanced Low-temperature Ceramic Nanocomposite Fuel Cells Using Ultra High Ionic Conductivity Electrolytes Synthesized Through Freeze-dried Method and Solid Route. Materials Today Energy. 5: 338-346.

[21] Wang, X. D., Y. Ma, R. Raza, M. Muhammed, and B. Zhu. 2008. Novel

Core-shell 
SDC/amorphous $\quad \mathrm{Na} 2 \mathrm{CO} 3$

Nanocomposite Electrolyte for Low-temperature SOFCs. Electrochemistry

Communications. 10(10): 16171620.

[22] Huang, J. B., Z. Q. Mao, Z. X. Liu, and C. Wang. 2008. Performance of Fuel Cells with Proton-conducting Ceria-based Composite Electrolyte and Nickel-based Electrodes. Journal of Power Sources. 175(1): 238243.

[23] Huang, W., P. Shuk, and M. Greenblatt. 1997. Properties of Sol-gel Prepared $\mathrm{Ce}_{(1-\mathrm{x})} \mathrm{Sm}_{(\mathrm{x})} \mathrm{O}_{(2-}$ $x / 2)$ Solid Electrolytes. Solid State Ionics. 100: 23-27.

[24] Zhu, B. 2009. Solid Oxide Fuel Cell (SOFC) Technical Challenges and Solutions from Nano-aspects. International Journal of Energy Research. 33(13): 1126-1137.

[25] Raza, R., X. D. Wang, Y. Ma, X. R. Liu, and B. Zhu. 2010. Improved Ceria-carbonate Composite Electrolytes.

International Journal of Hydrogen Energy. 35(7): 26842688.

[26] Gao, Z., R. Raza, B. Zhu, Z.Q. Mao, C. Wang, and Z. X. Liu. 2011. Preparation and Characterization of $\mathrm{Sm}_{0.2} \mathrm{Ce}_{0.8} \mathrm{O}_{1.9} / \mathrm{Na}_{2} \mathrm{CO}_{3}$

Nanocomposite Electrolyte for Low-temperature Solid Oxide Fuel Cells. International Journal of Hydrogen Energy. 36(6): 3984-3988.

[27] Zhao, Y. C., Z. R. Xu, C. Xia, and Y. D. Li. 2013. Oxide Ion and Proton Conduction in Doped Ceria-carbonate Composite
Materials. International Journal of Hydrogen Energy. 38(3): 1553-1559.

[28] Yin, S. L., Z. P. Ye, C. M. Li, X. W. Chen, and Y. W. Zeng. 2013. Theoretical Description on the Interface-enhanced Conductivity of SDC/LiNa-carbonate Composite Electrolytes. Materials Letters. 92: 78-81.

[29] Li, S. and J. C. Sun. 2010. Electrochemical Performances of NANOCOFC in MCFC Environments. International Journal of Hydrogen Energy. 35(7): 2980-2985.

[30] Zhu, B., I. Albinsson, C. Andersson, K. Borsand, M. Nilsson, and B. E. Mellander. 2006. Electrolysis Studies Based on Ceria-based Composites. Electrochemistry Communications. 8(3): 495-498.

[31] Qin, H. Y., Z. G. Zhu, Q. H. Liu, Y. F. Jing, R. Raza, S. Imran, M. Singh, G. Abbas, and B. Zhu. 2011. Direct Biofuel Lowtemperature Solid Oxide Fuel Cells. Energy \& Environmental Science. 4(4): 1273-1276.

[32] Amar, I. A., R. Lan, C. T. G. Petit, V. Arrighi, and S. W. Tao. 2011. Electrochemical Synthesis of Ammonia based on a Carbonate-oxide Composite Electrolyte. Solid State Ionics. 182(1): 133-138.

[33] Wade, J. L., C. Lee, A. C. West, and K. S. Lackner. 2011. Composite Electrolyte Membranes for High Temperature $\mathrm{CO}_{2}$ Separation. Journal of Membrane Science. 369(1-2): 20-29. 